\title{
Physical properties of honeys produced in the Northeast of Brazil
}

\author{
Patricia A. Costa ${ }^{\mathrm{a}}$, Izabel C.F. Moraes ${ }^{\mathrm{a}}$, Ana Mônica Q.B. Bittante ${ }^{\mathrm{a}}$, Paulo \\ J.A. Sobral ${ }^{a}$, Catarina A. Gomide ${ }^{a}$, And Celso C. CARrer ${ }^{a}$ \\ ${ }^{\mathrm{a}}$ Faculty of Animal Science and Food Engineering, University of São Paulo, Av. Duque de Caxias Norte, 225. \\ Pirassununga (SP) Brazil \\ ${ }^{*}$ Corresponding author \\ bel@usp.br
}

Received: 25 July 2012; Published online: 18 April 2013

\begin{abstract}
The aim of this work was to study the rheological, thermal and some other physical-chemical properties of selected honeys produced in the Northeast of Brazil. Two samples were produced by native "Jandaira" bees (Melipona subnitida) and ten other samples, by Africanized bees (Apis mellifera). The samples were analyzed for $\mathrm{pH}$, water activity $\left(\mathrm{a}_{w}\right)$, soluble solids and water content. Viscosity flow curves were obtained using a rheometer $\left(25^{\mathrm{o}} \mathrm{C}, 0-100 \mathrm{~s}^{-1}\right)$. Thermal analyses were performed on a differential scanning calorimeter, with heating rate of $10^{\mathrm{o}} \mathrm{C} / \mathrm{min}\left(-100\right.$ to $\left.100^{\circ} \mathrm{C}\right)$. The water content and the $\mathrm{pH}$ of the honey samples varied from 17.2 to $27.9 \%$ and from 3.2 to 4.2 , respectively, and, the $\mathrm{a}_{w}$ of the samples varied from 0.57 to 0.74 . Two samples were out of specification with respect to water content, according to Brazilian laws. In relation to rheology, all honey samples showed Newtonian behaviour with no thixotropy or dilatancy. The viscosity varied as an exponential function of the water content. The highest viscosity was obtained for the sample with lower values of water content and $\mathrm{a}_{w}$. Thermograms showed a glass transition $(\mathrm{Tg})$ occurring between -52.4 and $-42.6^{\circ} \mathrm{C}$, in the samples produced by Apis mellifera and -67.6 and $-57.0^{\circ} \mathrm{C}$ for the other samples. A linear relationship was obtained between $\mathrm{Tg}$ and water content. In conclusion, the honey viscosity depended on the water content of the product. The higher the water value and therefore the greater the $\mathrm{a}_{w}$, the lower viscosity and $\mathrm{Tg}$ of the samples.
\end{abstract}

Keywords: Viscosity; Glass transition; Water activity; DSC; Water content.

\section{Introduction}

Honey is produced from flower nectar and from plant secretions, and from the excretions of sucking insects, which the bees collect, transform and combine with specific substances and mature inside the honeycomb (Brasil, 2000). Usually, honey is a source of easily available sugars, organic acids, some amino acids, macro and micro nutrients and biologically active substances (Juszczak \& Fortuna, 2006). Beyond its high nutritional aspects, honey has medicinal- prophylactic value (Juszczak \& Fortuna, 2006; Viuda-Martos, Ruiz-Navajas, Fernández-López, \& Pérez-Álvarez, 2008; Aurongzeb \& Kamran Azim, 2011).

Regarding the physical-chemical properties, honey can be considered as a complex high concentrated sugar solution, composed mainly of glucose and fructose. Therefore, this product usually has an intermediate water activity value. This parameter is significant, as the free water amount affects the physical and biochemical stability of the honeys and it is important to de- 
fine safety regulations regarding undesirable microorganism growth, establishment of potential food risks, control of critical points and packaging needs (Souza, Marchini, Oda-Souza, Carvalho, \& Alves, 2009). Another consequence of its high concentration of sugars is that honey usually has high viscosity, which can be affected by the length of the molecular chain of the sugars (Bhandari, D'Arcy, \& Kelly, 1999).

Concerning the physical state, honey is considered a viscous glass where all the sugars are in the amorphous state (Bhandari et al., 1999), which may crystallize depending on sugar concentration, water content and temperature, among other factors. This process is undesirable and must be avoided or delayed as much as possible, as the product will acquire characteristics of an opaque semi-solid, decreasing the consumer acceptance. Moreover, some chemical characteristics of honey, such as $\mathrm{pH}$, soluble solids ( ${ }^{\circ}$ Brix), and water content are very important from the technological perspective. Also, the viscosity and the thermal properties are valuable as quality, process and storage parameters.

Nowadays, Brazil is ranked $11^{\text {th }}$ in world honey production (Freitas et al., 2010), with an estimated production of 37 thousand tonnes of honey/year in 2010. The northeast (NE) region of Brazil produces around $33.4 \%$ of the national amount (Sebrae, 2010). This region produces honey from Africanized bees, with sting (Apis mellifera), but also, from native stingless bees (Melipona subnitida). The honey from the stingless bees is a product which has showed increasing demand within the national market, with higher prices than those from the Africanized bees (Anacleto, Souza, Marchini, \& Moreti, 2009). However, there have been few studies that may help differentiate those honeys.

Several factors, as floral and geographic source, honey bee species, harvest season, can affect the composition of honey and consequently, the physical and chemical properties. One of the principal factors is the water content. Thus, considering that the knowledge of those factors may promote specific actions for preventing honey deterioration (physical, chemical, and/or microbiological) and/or extend its shelf life, the objective of this work was to study the rheological, thermal and some other physical-chemical properties (water content, soluble solids, water activity, $\mathrm{pH}$ ) of selected honeys produced in the Northeast of Brazil. This Brazilian region is a region with low rainfall and the physical-chemical characteristics of honeys produced in that region have not been studied.

\section{Materials and Methods}

The honeys studied in this work came from Rio Grande do Norte state, Brazil, of a zone including the cities of Lajes, Riachuelo, Angicos and Caiçara do Rio do Vento. This area is known as "Rainless polygon". The honeys were produced by small communities in the context of the familiar agriculture policies of Brazilian authorities. Two samples of honeys were produced by "Jandaira" bee (Melipona subnitida) (S1 and $\mathrm{S} 2$, in Table 1). The others were produced by Africanized bees (Apis mellifera) (S3 to S12). The honeys were produced from different floral origins and harvest seasons. The samples were collected between June 2008 and July 2009 by local producers and transported to Pirassununga immediately. The honeys were stored at refrigeration temperature the whole of the experimental period. Visual inspection of the samples did not show any crystal formation.

All samples were analyzed for determination of water activity $\left(\mathrm{a}_{w}\right), \mathrm{pH}$, soluble solids content $\left({ }^{\circ}\right.$ Brix) and water content. The water activity of the samples was measured at $22.7 \pm 0.5^{\mathrm{O}} \mathrm{C}$ using a water activity measuring equipment (Decagon, Aqualab CX-2). The $\mathrm{pH}$ of the samples was measured with a pH meter (Tecnal -TEC 2) in a $10 \%(\mathrm{w} / \mathrm{v})$ honey solution prepared with distilled water at $25^{\mathrm{o}} \mathrm{C}$. The soluble solids were determined using an Abbé refractometer ( ${ }^{\circ}$ Brix) and the water content was calculated from the refractive index at $20^{\circ} \mathrm{C}$, using the Chataway tables (A.O.A.C. 2003).

Rheological tests were carried out in a rheometer (AR2000 Advanced Rheometer, TA Instruments, New Castle DE, USA) using a cone and plate geometry $\left(4^{\underline{\mathrm{o}}}, 60 \mathrm{~mm}\right.$ diameter $)$. The temperature was controlled with a peltier system. Before undertaking rheological tests, all samples were held for at least $5 \mathrm{~min}$ between the upper cone and the lower fixed plate, to allow the stress 
$120 \mid$ Costa et al.

Table 1: Some physicochemical parameters of the honeys.

\begin{tabular}{cccccc}
\hline Sample & $\mathrm{pH}$ & $\begin{array}{c}\text { Soluble } \\
\text { Solids }\left({ }^{\circ} \text { Brix }\right)\end{array}$ & $\begin{array}{c}\text { Water content } \\
(\mathrm{g} / 100 \mathrm{~g})\end{array}$ & $\begin{array}{c}\text { Water } \\
\text { activity, } a_{w}\end{array}$ & Tg2 $\left({ }^{\mathrm{o}} \mathrm{C}\right)$ \\
\hline S1 & 3.22 & 70.5 & 27.9 & 0.740 & 47.74 \\
S2 & 3.31 & 74.8 & 23.8 & 0.671 & 51.92 \\
S3 & 3.77 & 80.2 & 18.0 & 0.585 & 55.31 \\
S4 & 3.57 & 77.8 & 20.8 & 0.633 & 47.08 \\
S5 & 4.19 & 80.5 & 17.8 & 0.585 & 42.15 \\
S6 & 3.79 & 79.2 & 19.2 & 0.606 & 52.21 \\
S7 & 3.69 & 81.0 & 17.2 & 0.574 & 49.74 \\
S8 & 3.67 & 78.8 & 19.6 & 0.609 & 54.44 \\
S9 & 3.57 & 79.0 & 19.4 & 0.616 & 52.37 \\
S10 & 3.72 & 79.0 & 19.4 & 0.618 & 46.72 \\
S11 & 3.66 & 76.8 & 21.6 & 0.642 & 52.85 \\
S12 & 3.64 & 80.2 & 18.0 & 0.586 & 52.69 \\
\hline
\end{tabular}

relaxation induced during sample loading. To avoid water losses due to evaporation, the measurement system was coated with a solvent trap accessory. Steady shear measurements were performed at the steady state, at $25^{\mathrm{O}} \mathrm{C}$, with a shear rate range of $0-100 \mathrm{~s}^{-1}$ in two ramps: ascending and descending. Data were analyzed by Rheological Advantage Data Analysis V.5.3.1 Software (TA Instruments). All rheological measurements were carried out in duplicate.

The phase transition properties of the honeys were studied using a differential scanning calorimeter (DSC, TA Instruments, USA, model TA 2010, with controlling module Thermal Advantage Version 1.1A) and cooling accessory (Sobral \& Bittante, 2001). Samples of the honeys were weighed $(\sim 10 \mathrm{mg})$ on an analytical scale $( \pm 0.01 \mathrm{mg})$ inside hermetically sealed aluminum pans. The samples were heated from -100 to $100^{\circ} \mathrm{C}$, at $10^{\circ} \mathrm{Cmin}^{-1}$. An empty aluminum pan was used as reference. The results were analyzed using the Universal Analysis 2000 software version 4.2E (TA Instruments). Reported data are the average of duplicate determinations.

The data was submitted to an analysis of variance (ANOVA) and by Tukey's HSD test, with $\mathrm{p} \leq 0.05$, using the Statistical Analysis System (V. 9.2) (SAS Institute Inc. SAS/STAT ${ }^{\circledR}, 2008$ ). The coefficients of correlation of linear and nonlinear regressions of some data were calculated using the Software Excel 2007 (Microsoft ${ }^{\circledR}$ Office Excel $^{\circledR}$, 2008).

\section{Results and discussion}

All the honey samples presented $\mathrm{pH}$ values of between 3.22 and 4.19, with samples $\mathrm{S} 1$ and $\mathrm{S} 2$ (honeys produced by stingless bees) being the ones with the lowest $(\mathrm{p} \leq 0.05) \mathrm{pH}$ values (Table 1 ). These results suggested that no deterioration occurred in these samples. The $\mathrm{pH}$ values of the honeys were consistent with the results of Argentine honeys, in which the $\mathrm{pH}$ ranged between 3.1 and 4.1 (Baroni et al., 2009), but lower than those obtained for Turkish honeys ( $\mathrm{pH} 3.67$ - 4.57) (Kayacier \& Karaman, 2008), Spanish honeys (pH 3.55 - 4.79) (Terrab, Recamales, Hernanz, \& Heredua, 2004), and Algerian honeys (pH 3.49 - 4.53) (Ouchemoukh, Louaileche, \& Schweitzer, 2007).

The honeys effectively consisted of concentrated solutions of soluble solids, with values varying between 70 and $81^{\circ}$ Brix (Table 1). Again, the honeys produced by the stingless bees presented the lower $(\mathrm{p} \leq 0.05)^{\circ}$ Brix values.

Due to the low soluble solids contents, the water content from the stingless bees (S1) was the highest $(p \leq 0.05)$, but, overall, this parameter varied between 17.2 and $27.9 \mathrm{~g} / 100 \mathrm{~g}$ for all samples (Table 1). According to Brazilian laws, based 
on the standards for honey produced by Apis mellifera, the maximum water content value allowed for honey is $20 \mathrm{~g} / 100 \mathrm{~g}$ (Brasil, 2000). Thus, two samples (S4 and S11) did not satisfy the requirements of the Brazilian Standard. Nevertheless, the values obtained for samples S1 and S2 were within the upper limit (35\%) suggested for honeys from Melipona subnitida in Brazil (VillaBoas \& Malaspina, 2005). The water content of honey may vary according to the botanic origin of the flowers, geographic location, climate conditions, harvest prior to complete maturation and honey bee type (Nanda, Sarkar, Sharma, \& Bawa, 2003). The water content values determined in this study agree with the values reported for Chinese honeys (19.8 - 29.0\%) (Junzheng \& Changying, 1998), but are higher than those reported for honeys from Australia (15.8 $18.0 \%$ ) (Sopade et al., 2002), from Poland (15.4 - 18\%) (Juszczak \& Fortuna, 2006), from Mexico (16 - 20.6\%) (Mora-Escobedo, Moguel-Ordonez, Jaramillo-Flores, \& Gutierrez-Lopez, 2006), and by Argentine [16.4 - 20.2\% (Baroni et al., 2009) and $15-21 \%$ (Chirife, Zamora, \& Motto, 2006)]. Kuroishi, Queiroz, Almeida, and Quast (2012) studied some characteristics of honey produce in the South of Brazil (Paraná state) and determined an average value of $17.55 \pm 0.42 \%$ for water moisture.

The water activity $\left(\mathrm{a}_{w}\right)$ values of the honeys varied within the range $0.574-0.740$ (Table 1). The water activity of honey was due to its sugar composition and concentration (Gleiter, Horn, \& Isengard, 2006), but also to the water content (Mora-Escobedo et al., 2006; Chirife et al., 2006; Gleiter et al., 2006; Cavia, Fernandez-Muino, Huidobro, \& Sancho, 2004). The results of this work agree with these as the water activity varied linearly (Equation 1) with the water content (Figure 1), similarly to observed by Cavia et al., 2004. The $\mathrm{a}_{w}$ data presented in Table 1 were within the range reported for meliponid honeys from São Paulo state - Brazil (0.662 0.851) (Anacleto et al., 2009), but in general, those values were higher than those obtained for Greek honeys (0.528 - 0.663) (Larazidou, Biliaderis, Bacandritsos, \& Sabatini, 2004), Turkish honeys (0.51-0.52) (Kayacier \& Karaman, 2008) and Spanish honeys $(0.52-0.57)$ (Serrano, Villarejo, Espejo, \& Jodral, 2004). Those $a_{w}$ values allow the classification of honey as an intermediate moisture food, and thus, it is shelf stable for a reasonable period of time. The low $\mathrm{a}_{w}$ does not allow microbial growth or fermentation of honey by osmophilic yeasts (Larazidou et al., 2004).

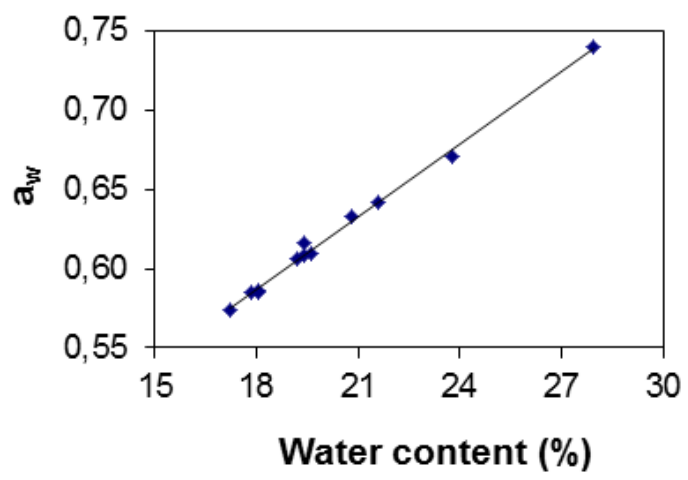

Figure 1: Water activity $\left(\mathrm{a}_{w}\right)$ as a function of water content of the analyzed honeys.

$$
a_{w}=0.015 X+0.311\left(R^{2}=0.996\right)
$$

Regarding the rheological studies of the honeys, all samples showed Newtonian behaviour at $25^{\circ} \mathrm{C}$ (Figure 2), agreeing with a number of published results (Larazidou et al., 2004; Zaitoun, Ghzawi, Al-Malah, \& Abu-Jdayil, 2001; Abu-Jdayil, Ghzawi, Al-Malah, \& Zaitoun, 2002; Costa \& Pereira, 2002; Kumar \& Mandal, 2009; Wei, Wang, \& Wang, 2010), although there are authors that reported viscoelastic behaviour in honeys (Oh \& Yoo, 2011). It is usual behaviour for a low molecular weight component concentrated solution. The absence of either thixotropic or dilatant phenomena could be explained by the absence of macromolecules and/or particles in suspension. The viscosity of the honey varied from 6.65 to 0.19 Pa.s as an exponential function of the water content of the samples (Figure 3), according to Equation 2. This behaviour of the honey viscosity was also observed by other authors (Juszczak \& Fortuna, 2006; Sopade et al., 2002; Zaitoun et al., 2001; Mossel, B and Bhandari, B and D'Arcy, B and Caffin, N, 2000).

$$
\begin{array}{r}
\eta=2116.1 \exp (-0.338 X)\left(R^{2}=0.982\right), \\
\text { where } \mathrm{X} \text { is the water content }
\end{array}
$$



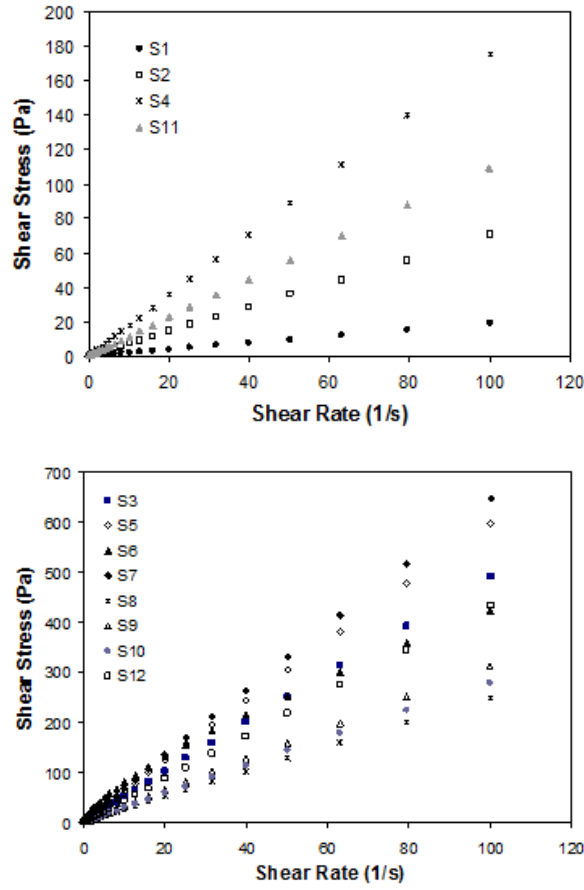

Figure 2: Examples of flow curves for honeys at $25^{\mathrm{O}} \mathrm{C}$.

The viscosity values of the honeys studied in this work were similar to those of Chinese honeys ( 0.3 - 6.3 Pa.s) (Junzheng \& Changying, 1998), analyzed at $20^{\circ} \mathrm{C}$, but were lower than those of Jordanian honey (12.18 - 30 Pa.s) (Abu-Jdayil et al., 2002), Polish honeys (9 - 21.5 Pa.s) (Juszczak \& Fortuna, 2006) and Indian honeys (2.68 - 11.35 Pa.s) (Kumar \& Mandal, 2009), all determined at $25^{\underline{\mathrm{o}}} \mathrm{C}$. It is well known that the viscosity of honey is strongly influenced by water content, and by the chemical composition of the honey dried solids. All these parameters can vary with natural conditions such as season of year, geographical region, etc (Juszczak \& Fortuna, 2006; Zaitoun et al., 2001). These facts could explain the exponential decays of honey viscosity, differently from other properties, which varied linearly with water content.

The heat flow curves obtained during the differential scanning calorimetry analyses presented typical behaviour for honeys (Figure 4). A glass transition, which must be associated to the amor-

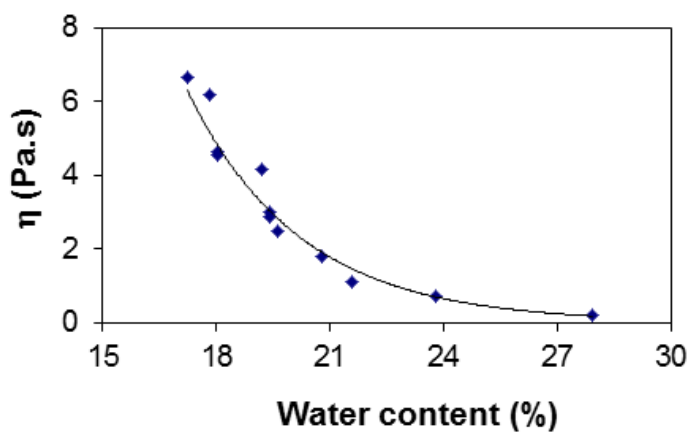

Figure 3: Viscosity $(\eta)$ as a function of the water content of the analysed honeys.

phous dry solids of honey, was observed occurring at a very low temperature, between -67.23


tures $(\mathrm{Tg})$ varied linearly (Equation 3) with the water content $(\mathrm{X})$ of the samples (Figure 5), due to the strong plasticizing effect of the water molecules, which causes the depression of the $\mathrm{Tg}$ of completely amorphous and partially crystalline food products (Cordella et al., 2002).

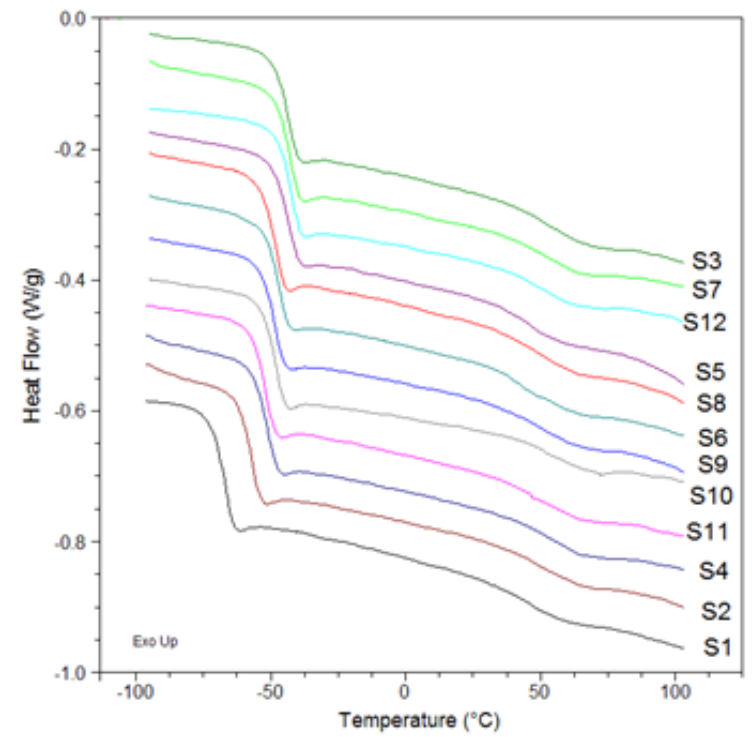

Figure 4: Examples of the DSC thermograms of the analysed honeys.

$$
T g=-2.310 X-2.561\left(R^{2}=0.996\right)
$$




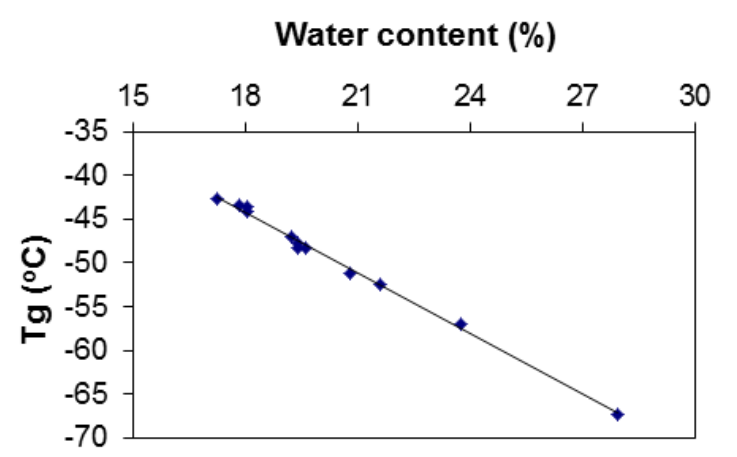

Figure 5: Lower glass transitions temperatures $(\mathrm{Tg})$ as a function of the water content of the analysed honeys.

The $\mathrm{Tg}$ values obtained in this study were higher than those obtained for Greek honeys (-34.6 and $47.2^{\mathrm{O}} \mathrm{C}$ ) (Larazidou et al., 2004), Australian honeys $\left(-40\right.$ and $\left.-46^{\circ} \mathrm{C}\right)$ (Sopade et al., 2002), and Indian honeys (-33.64 and $-51.14^{\mathrm{O}} \mathrm{C}$ ) (Ahmed, Prabhu, Raghavan, \& Ngadi, 2007). As it is well known that the honey composition in terms of type of sugars might also affect its $\mathrm{Tg}$ (Larazidou et al., 2004; Cordella et al., 2002; Ahmed et al., 2007), it may be suggested that the sugar composition of Brazilian honeys must be very similar. Normally, the major sugars present in honey are fructose and glucose (Ouchemoukh et al., 2007; Kaskoniene, Venskutonis, \& Ceksteryte, 2010). A second glass transition appeared at intermediate temperatures (Table 1), between 42 and $55^{\circ} \mathrm{C}$, but not necessarily plasticized by water, considering that monotonic behaviour was not observed. Cordella et al. (2002) observed an endothermal phenomenon in that position, but in the present work, no ice melting was observed in the thermograms (Figure 4).

Understanding the properties of honeys at low temperatures is of a prime importance for their proper storage (Juszczak \& Fortuna, 2006). Moreover, Cordella et al. (2002) suggested a new method for determining the adulteration of honey using the determinations of $\mathrm{Tg}$ and other thermal events detected by DSC. So, considering that the properties we studied were a function of the water content, it could be possible to determine adulteration by water addition. To verify this, other methods must be tested against adulterations (Guo, Liu, Zhu, \& Wang, 2011).

\section{Conclusions}

Analysis of some selected Brazilian honeys produced in the northeast region revealed that the floral source and honey bee species affected the quality parameters by affecting the water moisture of the samples, with exception for the $\mathrm{pH}$ and the soluble solids. Each honey type was shown to have properties that could be expressed as a function of its water content. The water activity of honey increased linearly with the sample water content. All samples showed Newtonian behaviour and their viscosity reduced exponentially as the water content increased. The glass transition temperature for the honey samples decreased linearly with the water content, exhibiting the strong depression effect of water molecules. These results could be used for processing, product development and storage of honey and honey based products, as well as to verify the quality and check for adulteration.

\section{References}

Abu-Jdayil, B, Ghzawi, A., Al-Malah, K., \& Zaitoun, S. (2002). Heat effect on rheology of light- and dark-colored honey. Journal of Food Engineering, 51(1), 33-38. doi:10. 1016/S0260-8774(01)00034-6

Ahmed, J., Prabhu, S. T., Raghavan, G. S. V., \& Ngadi, M. (2007). Physico-chemical, rheological, calorimetric and dielectric behavior of selected Indian honey. Journal of Food Engineering, 79(4), 1207-1213. doi:10.1016/j.jfoodeng.2006.04.048

Anacleto, D., Souza, B., Marchini, L., \& Moreti, A. (2009). Composição de amostras de mel de abelha de jataí (Tetragonisca angustula latreille, 1811). Ciência e Tecnologia de Alimentos, 29(3), 535-541.

A.O.A.C. (2003). Official methods of Analysis. 17 ed.,Gaithersburg, MD, USA.

Aurongzeb, M., \& Kamran Azim, M. (2011). Antimicrobial properties of natural honey: a review of literature. Pak. J. Biochem. Mol. Biol. 118-124(3), 44. 
Baroni, M., Arrua, C., Nores, M., Fayé, P., Díaz, M., Chiabrando, G., \& Wuderlin, D. (2009). Composition of honey from córdoba (argentina): assessment of north/south provenance by chemometrics. Food Chemistry, 114, 727-733.

Bhandari, B., D'Arcy, B., \& Kelly, C. (1999). Rheology and crystallization kinetics of honey: present status. International Journal of Food Properties, 2(3), 217-226.

Brasil. (2000). Leis, Decretos, etc. 2000 Instrução normativa 11. Regulamento Técnico de Identidade e Qualidade do Mel. Diário Oficial, 20 de outubro de 2000. Retreived in October 2010. Retrieved from http://www. agricultura.gov.br

Cavia, M., Fernandez-Muino, M., Huidobro, J., \& Sancho, M. (2004). Correlation between moisture and water activity of honeys harvested in different years. Journal of Food Science, 69(5), C368-C370.

Chirife, J, Zamora, M., \& Motto, A. (2006). The correlation between water activity and \% moisture in honey: Fundamental aspects and application to Argentine honeys. Journal of Food Engineering, 72(3), 287-292. doi:10.1016/j.foodeng.2004.12.009

Cordella, C, Antinelli, J., Aurieres, C, Faucon, J., Cabrol-Bass, D, \& Sbirrazzuoli, N. (2002). Use of differential scanning calorimetry (DSC) as a new technique for detection of adulteration in honeys. 1. Study of adulteration effect on honey thermal behavior. Journal of Agricultural and Food Chemistry, 50(1), 203-208. doi:10.1021/ jf010752s

Costa, C., \& Pereira, R. (2002). The influence of propolis on the rheological behavior of pure honey. Food Chemistry, 76 (4), 417-421.

Freitas, W., Aroucha, E., Soares, K., Mendes, F., Oliveria, V., Lucas, C., \& Santos, M. (2010). Parâmetros físico-químicos do mel de abelha sem ferrão (melípona subnitida) após tratamento térmico. Acta Veterinária Brasilica, 4(3), 153-157.

Gleiter, R., Horn, H, \& Isengard, H. (2006). Influence of type and state of crystallisation on the water activity of honey. Food Chemistry, 96(3), 441-445. doi:10.1016/j. foodchem.2005.03.051
Guo, W., Liu, Y., Zhu, X., \& Wang, S. (2011). Dielectric properties of honey adulterated with sucrose syrup. Journal of Food Engineering, 107(1), 1-7. doi:10.1016/ j . jfoodeng.2011.06.013

Junzheng, P., \& Changying, J. (1998). General rheological model for natural honeys in china. Journal of Food Engineering, 36(2), 165-168.

Juszczak, L, \& Fortuna, T. (2006). Rheology of selected Polish honeys. Journal of Food Engineering, 75(1), 43-49. doi:10.1016/ j . jfoodeng.2005.03.049

Kaskoniene, V., Venskutonis, P. R., \& Ceksteryte, V. (2010). Carbohydrate composition and electrical conductivity of different origin honeys from Lithuania. $L W T$ Food Science and Technology, 43(5), 801807. doi:10.1016/j.lwt.2010.01.007

Kayacier, A., \& Karaman, S. (2008). Rheological and some physicochemical characteristics of selected Turkish honeys. Journal of Texture Studies, 39(1), 17-27. doi:10.1111/ j.1745-4603.2007.00127.x

Kumar, J., \& Mandal, M. (2009). Rheology and thermal properties of marketed indian honey. Nutrition \& Food Science, 39(2), 111-117.

Kuroishi, A., Queiroz, M., Almeida, M., \& Quast, L. (2012). Evaluation of honey crystallization from the colour and water activity parameters. Brazilian Journal of Food Technology, 15, 84 -91. doi:10.1590/S1981 67232012000100009

Larazidou, A., Biliaderis, C., Bacandritsos, N., \& Sabatini, A. (2004). Composition, thermal and rheological behavior of selected greek honeys. Journal of Food Engineering, 64, 9-21.

Microsoft ${ }^{\circledR}$ Office Excel ${ }^{\circledR}$. (2008). Microsoft ${ }^{\circledR}$ Office Excel ${ }^{\circledR}$ 2007, Copyright (C)2008.

Mora-Escobedo, R, Moguel-Ordonez, Y, Jaramillo-Flores, M., \& Gutierrez-Lopez, G. (2006). The composition, rheological and thermal properties of Tajonal (Viguiera dentata) Mexican honey. International Journal of Food Properties, 9(2), 299-316. doi:10.1080/10942910600596159

Mossel, B and Bhandari, B and D'Arcy, B and Caffin, N. (2000). Use of an Arrhe- 
nius model to predict rheological behaviour in some Australian honeys. LebensmittelWissenschaft Und-Technologie-Food Science and Technology, 33(8), 545-552. doi:10.1006/fstl.2000.0714

Nanda, V, Sarkar, B., Sharma, H., \& Bawa, A. (2003). Physico-chemical properties and estimation of mineral content in honey produced from different plants in Northern India. Journal Of Food Composition And Analysis, 16(5), 613-619. doi:10 . 1016/ S0889-1575(03)00062-0

Oh, J.-H., \& Yoo, B. (2011). Effect of Temperature on the Relationship between Moisture Content and Dynamic Rheological Properties of Korean Honey. Food Science and Biotechnology, 20(1), 261-265. doi:10. 1007/s10068-011-0036-3

Ouchemoukh, S., Louaileche, H., \& Schweitzer, P. (2007). Physicochemical characteristics and pollen spectrum of some Algerian honeys. Food Control, 18(1), 52-58. doi:\{10. 1016/j.foodcont.2005.08.007\}

SAS Institute Inc. SAS/STAT ${ }^{\circledR} . \quad$ (2008). OnlineDoc ${ }^{\circledR}$, Version 9.2, Copyright (C)2008, February 2008.

Sebrae. (2010). Accessed February 2010. Retrieved from www.sebrae.com.br/setor / apicultura/

Serrano, S, Villarejo, M, Espejo, R, \& Jodral, M. (2004). Chemical and physical parameters of Andalusian honey: classification of Citrus and Eucalyptus honeys by discriminant analysis. Food Chemistry, 87(4), 619-625. doi:10.1016/j.foodchem.2004.01.031

Sobral, P., \& Bittante, A. (2001). Phase transition of pigskin gelatin. Food Hydrocolloids, 15(4-6), 377-382.

Sopade, P., Halley, P, Bhandari, B, D'Arcy, B, Doebler, C, \& Caffin, N. (2002). Application of the williams-landel-ferry model to the viscosity-temperature relationship of australian honeys. Journal of Food Engineering, 56(1), 67-75. doi:10.1016/S02608774(02)00149-8

Souza, B., Marchini, L., Oda-Souza, M., Carvalho, C., \& Alves, R. (2009). Caracterização do mel produzido por espécie de melipona illiger, 1806 (apidae: meliponini) da região do nordeste do brasil: 1. Carac- terísticas Físico-Químicas. Química Nova, 32(2), 303-308.

Terrab, A., Recamales, A., Hernanz, D., \& Heredua, F. (2004). Characterization of spanish thyme honeys by their physicochemical claracteristics and mineral contents. Food Chemistry, 88(4), 537-542.

Villa-Boas, J., \& Malaspina, O. (2005). Parâmetros físico-químicos propostos para controle de qualidade do mel de abelhas sem ferrão no brasil. mensagem doce. 82, 6-16.

Viuda-Martos, M., Ruiz-Navajas, Y., FernándezLópez, J., \& Pérez-Álvarez, J. (2008). Functional properties of honey, propolis, and royal jelly. Journal of Food Science, $73(9), \mathrm{R} 117-\mathrm{R} 124$.

Wei, Z., Wang, J., \& Wang, Y. (2010). Classification of monofloral honeys from different floral origins and geographical origins based on rheometer. Journal of Food Engineering, 96(3), 469-479. doi:10.1016/j. jfoodeng.2009.08.028

Zaitoun, S, Ghzawi, A, Al-Malah, K., \& AbuJdayil, B. (2001). Rheological properties of selected light colored Jordanian honey. International Journal of Food Properties, 4 (1), 139-148. doi:10.1081/JFP-100002192 